\title{
O INESGOTÁVEL E ELEGANTE TRABALHO DA MEMÓRIA, QUE RECONSTRÓI, PERFORMA E ELABORA
}

\author{
RONALDO MANZI FILHO \\ FACMAIS \\ Inhumas | Goiás | Brasil \\ manzifilho@hotmail.com \\ orcid.org/0000-0001-7980-3997 \\ MARIA LETÍCIA DE OLIVEIRA REIS \\ Psicanalista \\ São Paulo | São Paulo | Brasil \\ marileoliveira@hotmail.com \\ orcid.org/0000-0003-3790-7071
}

O presente texto visa repensar a compreensão da autobiografia e do diário: memória, reconstrução e memória performativa versus instantaneidade e tempo congelado. Articulando a filosofia de Walter Benjamin, no que concerne à perda de experiência do sujeito moderno e sua incapacidade de narrar, trazemos ao debate a acepção de memória em psicanálise e sua relação ao esquecimento e a elaboração. A forma diário que domina as redes sociais nos mostra uma mudança significativa de nossa forma de ser (de nossa forma de lidar com nossa própria história), em que a "sinceridade", a exigência do imediato, seja o "mais real". O que está em jogo nessa mudança - de uma escrita de si que era guardada à sete chaves à exposição de si diária nas redes sociais? 


\title{
THE INEXHAUSTIBLE AND ELEGANT WORK OF MEMORY, WHICH REMAKES, PERFORMS AND ELABORATES
}

\author{
RONALDO MANZI FILHO \\ FACMAIS \\ Inhumas | Goiás | Brazil \\ manzifilho@hotmail.com \\ orcid.org/0000-0001-7980-3997 \\ MARIA LETÍCIA de OLIVEIRA REIS \\ Psychoanalyst \\ São Paulo | São Paulo | Brazil \\ marileoliveira@hotmail.com \\ orcid.org/0000-0003-3790-7071
}

This text aims to rethink the understanding of autobiography and diary: memory, reconstruction and performative memory versus instantaneity and frozen time. Articulating Walter Benjamin's philosophy, regarding the loss of experience of the modern subject and his inability to narrate, we bring to the debate the meaning of memory in psychoanalysis and its relation to forgetfulness and elaboration. The diary form that dominates social networks shows us a significant change in our way of being (in our way of dealing with our own history), in which "sincerity", the requirement of the immediate, is the "most real". What is at stake in this change - from writing about yourself that was kept under lock and key to the daily exposure of the self on social networks? 
O começo do século XX foi marcado por uma reflexão sobre a perda da experiência como insistiu Walter Benjamin. Por outro lado, as reflexões psicanalíticas de Sigmund Freud, que são contemporâneas de Benjamin, nos remetem a repensar o que compreendemos por memória. A questão de como narramos nossa própria experiência não parece ser a mesma: há uma diferença significativa entre as autobiografias e os diários que encontramos hoje nas redes sociais. Esse texto busca discutir essa perda de experiência tal como trabalhada por Benjamin em Experiência e pobreza (1933):

\begin{abstract}
Não, está claro que as ações da experiência estão em baixa, e isso numa geração que entre 1914 e 1918 viveu numa das mais terríveis experiências da história. Talvez isso não seja tão estranho quanto parece. Na época, já se podia notar que os combatentes tinham voltado silenciosos do campo de batalha. Mais pobres em experiências comunicáveis, e não mais ricos. Os livros de guerra que inundaram o mercado literário nos dez anos seguintes não continham experiências transmissíveis de boca em boca. Não, o fenômeno não é estranho. Porque nunca houve experiências mais radicalmente desmoralizadas que a experiência estratégica pela guerra de trincheiras, a experiência econômica pela inflação, a experiência do corpo pela fome, a experiência moral pelos governantes (Benjamin 1994, 115, grifo nosso).
\end{abstract}

A noção de experiência que nos interessa diz respeito a uma perda, como a citação acima demonstra; e essa perda, da qual o sujeito moderno não mais escapou, concerne a uma transmissão, a um falar de si. O sujeito perde sua capacidade de narrar. Na citação anterior, não somente importa o que se perde, mas como se perde: a forma como os combatentes voltavam silenciados impressionou Benjamin porque se tratava de um momento de guerra, em que deveriam ter o que dizer; em vez disso, eles se silenciaram. Aqui se abre um campo discursivo vastíssimo, pois foi exatamente nesse contexto de guerra que Freud escreveu importantes textos (sem ter conhecimento da obra de Benjamin), demonstrando, debatendo e enfrentando as dificuldades das perdas do sujeito e de suas próprias, ao longo da vida.

\title{
A METÁFORA DO ARQUEÓlOGO EM PSICANÁLISE E O TRABALHO DA MEMÓRIA
}

Benjamin, em um trecho denominado Escavando e recordando que se encontra em suas Imagens do pensamento, trata de uma forma de correlacionar a memória, a história e a redenção do passado. Na verdade, Benjamin se inspira em Sigmund Freud:

A língua tem indicado inequivocamente que a memória não é um instrumento para a exploração do passado; é, antes, o meio. É o meio onde se deu a vivência, assim como o solo é o meio no qual as antigas cidades estão soterradas. Quem pretende se aproximar do próprio passado soterrado deve agir como um homem que escava. Antes de tudo, não deve temer voltar sempre ao mesmo fato, espalhá-lo como se espalha a terra, revolvê-lo como se revolve o solo. Pois 'fatos' nada são além de camadas que apenas à exploração mais cuidadosa entregam aquilo que recompensa a escavação. Ou seja, as imagens que, desprendidas de todas as conexões mais primitivas, ficam como preciosidades nos sóbrios aposentos de nosso entendimento tardio, igual a torsos na galeria do colecionador. E certamente é útil avançar em escavações segundo planos. Mas é igualmente indispensável a enxada cautelosa e tateante na terra escura. E se ilude, privando-se do melhor, quem só faz o inventário dos achados e não sabe assinalar no terreno de hoje o lugar no qual é conservado o velho. Assim, verdadeiras lembranças devem proceder informativamente muito menos do que 
indicar o lugar exato onde o investigador se apoderou delas. A rigor, épica e rapsodicamente, uma verdadeira lembrança deve, portanto, ao mesmo tempo, fornecer uma imagem daquele que se lembra, assim como um bom relatório arqueológico deve não apenas, indicar as camadas das quais se originam seus achados, mas também, antes de tudo, aquelas outras que foram atravessadas anteriormente (Benjamin 1987, 239-240, grifo nosso).

A metáfora da arqueologia é utilizada bastante por Freud. Ele a escreveu em vários momentos que uma forma de se imaginar a análise seria como a descoberta de ruínas. Por exemplo, ao se encontrar uma cidade antiga, encontramos pequenos vestígios, tais como vasos, cerâmicas, algumas construções que indicam como essa cidade seria no passado. O trabalho do arqueólogo seria uma forma de reconstrução desse passado a partir dessas ruínas, desses traços deixados. Mas, obviamente, por mais que o arqueólogo seja astuto em reconstruir essa cidade, ele jamais a reconstruiria tal como ela "foi na realidade". O trabalho do arqueólogo exige uma reconstrução que jamais poderá ter qualquer verificação real se essa construção corresponde ou não ao que essa cidade era.

$\mathrm{Na}$ psicanálise, segundo Freud, não seria diferente. $\mathrm{O}$ analisando, em sua fala, traz pequenas ruínas de memórias, alguns traços, que devem ser reconstruídos para que ele mesmo monte uma nova cidade - uma nova realidade psíquica, no caso. Na verdade, Freud vê uma vantagem na psicanálise: mesmo que não tenhamos acesso "à cidade tal como era" ("à memória tal como aconteceu"), temos a possibilidade de reconstruir uma história com o analisando. Essas ruínas foram ele mesmo que trouxe e ele mesmo pode criar algo com isso. Assim, nada que é reconstruído pode ter qualquer verificabilidade. O que se tem é uma ressignificação do passado a partir de traços. Eis porque Jacques Lacan, na esteira de Freud, irá afirmar que: “A reconstrução histórica promovida pelo tratamento não muda a história, mas a posição do sujeito em relação à sua história." (Lacan 1953, 21).

O analisando não se lembra senão de traços - aqueles que deixaram marca. É verdade que nada está completamente destruído no aparelho psíquico; o que encontramos são traços. E o que a pessoa traz à tona é uma seleção de traços que ressignifica a sua própria história.

Mas Freud coloca um limite a essa analogia com a arqueologia:

[...] o objeto psíquico é incomparavelmente mais complicado que o material do arqueólogo e nosso conhecimento não está suficientemente preparado para o que devemos encontrar, pois a estrutura intima deste ainda esconde muita coisa misteriosa. E nossa comparação dos dois trabalhos chega ao fim, pois a principal diferença entre eles consiste em que, para a arqueologia, a reconstrução é a meta e o fim dos esforços, e, para a análise, a construção é apenas um trabalho prévio.

(Freud 2018, 331-332).

A análise seria mais complicada porque não tem também nenhuma sequência lógica - ela caminha tal como vai aparecendo e vai sendo construído não partes que se integram, mas uma reconstrução permanente a partir de cada fragmento novo. Ou seja, um novo fragmento muda a estrutura do que se estava construindo. Uma sessão de análise pode construir uma "cidade" completamente diferente de outra sessão. Afinal, inaugurar uma nova forma de relacionar com seu passado é uma função clínica que exige um trabalho (Arbeit). A função das lembranças, do esquecimento, ou seja, a concepção da memória no tratamento psicanalítico diz respeito a uma ressignificação possibilitada pelo trabalho de elaboração (Durcharbeiten). 
O que Freud propõe é que a convicção da verdade da construção tem o mesmo valor que uma lembrança reconquistada - a construção vale como se fosse real, isso porque a construção se vale de traços da memória (melhor dizendo, "grãos de verdade"). É em relação a esses grãos de verdade que Freud tem o intuito de associar a fantasia com a construção em análise. Essa análise de Freud da memória inspira também Jacques Lacan a afirmar que:

\begin{abstract}
As ciências e, sobretudo, as ciências em parto como a nossa, tomam emprestado frequentemente modelos de outras ciências. Vocês não imaginam, meus pobres amigos, o que devem à geologia. Se não houvesse geologia, como chegaríamos a pensar que podemos passar, no mesmo nível, de um leito recente a um leito anterior? Não faria mal, digo de passagem, que todo analista comprasse um pequeno livro de geologia (Lacan 1975, 88-89).
\end{abstract}

Um outro ponto a se notar é como a memória, ao ser reconstruída, pode nos levar a agir de outra forma. É como se uma memória reconstruída fosse capaz de nos mudar. Foi isso que foi denominado recentemente memória performativa:

\begin{abstract}
Memória performativa seria uma memória construída a partir de um testemunho que tem o poder de mudar a forma de ser de uma pessoa. Ou seja, mesmo que toda memória seja social, mesmo que seja uma construção, nem todas as memórias construídas sob o testemunho de outro tem a mesma potência no sujeito. Certas memórias simplesmente preenchem lacunas que dão sentido ao que vivenciamos. Ao ressignificar algo acontecido damos um novo sentido ao que pensamos sobre nós mesmos, sem que tal memória tenha qualquer relação a um estado de coisas. Por outro lado, certas memórias, como o sonho do Homem dos lobos, podem ser ressignificadas num terceiro momento e modificam nossa forma de ser - nada do que foi antes será o mesmo depois da ressignificação desse tipo de memória. Ela teria um poder performativo sobre a forma de ser do sujeito. Uma espécie de insight. Em análise, nem sempre a construção de uma memória chega a ter tal poder. Mas em alguns momentos, a simples construção de uma memória poderá modificar o que somos, tal como na fala performativa: quando se diz 'eu aceito' (Manzi 2019, 39-40, grifo nosso).
\end{abstract}

A memória seria então ligada a uma reconstrução e a um ato performativo. Poderíamos ainda lembrar de uma passagem curiosa de Maurice Merleau-Ponty em que ele associa o fenômeno do membro fantasma com a concepção de Marcel Proust de "busca do tempo perdido".

Merleau-Ponty associa a questão de uma busca de um tempo perdido com a quase-presença do passado. O mesmo aconteceria com o fenômeno do membro fantasma: ele está quase-presente para o sujeito. Como se pudéssemos descrever um personagem que encontra algum sentido na sua vida presente se filiando a um tempo perdido: 


\begin{abstract}
O amputado sente sua perna como eu posso sentir vivamente a existência de um amigo que não está, todavia, sob meus olhos; ele não a perdeu porque continua a contar com ela, como Proust pode bem constatar a morte de sua avó sem a perder ainda enquanto a conserva no horizonte de sua vida. O braço fantasma não é a representação de braço, mas a presença ambivalente de um braço. A recusa da mutilação no caso do membro fantasma ou a recusa da deficiência na anosognose não são decisões deliberadas, não se passam no nível da consciência tética que toma posição explícita depois de ter considerado diferentes possíveis. A vontade de ter um corpo são ou a recusa do corpo doente não são formulados por eles mesmos, a experiência do braço amputado como presença on do braço doente como ausente não são da ordem do 'eu penso que...' (Merleau-Ponty 1967, 96, grifo nosso).
\end{abstract}

Ou seja, a forma de pensarmos o presente é ampliada: ela envolve a quase-presença do passado. Há algo que deve ser destacado: aquele traço que nos diz Freud. Merleau-Ponty o toma como "algo que devemos contar com". Jeanne Marie Gagnebin lê Proust de forma próxima: "busca das analogias e das semelhanças entre o passado e o presente. Proust não reencontra o passado em si - que talvez fosse bastante insosso -, mas a presença do passado no presente e o presente que está lá, prefigurado no passado (...)" (Gagnebin In Benjamin 1994, 15).

Gagnebin nos traz essa reflexão ao pensar em Walter Benjamin. Isso lhe possibilitava pensar a memória de outro modo, ligada à própria situação do sujeito. Esta passagem de Ernani Chaves é bem esclarecedora:

\begin{abstract}
[...] a obra proustiana não descreve uma vida tal qual ela foi - [...] - mas a vida lembrada por aquele que a vivenciou - [...]. Em termos freudianos, poderíamos dizer que o passado, evocado pelo adulto, se constitui sempre numa 'lembrança encobridora': 'Nossas lembranças de infância não nos mostram os primeiros anos de vida como eles foram, mas como se apresentam, posteriormente, na época de sua evocação' (Chaves In Safatle; Manzi 2008, 37-38).
\end{abstract}

Freud adverte na História de uma neurose infantil (1918) o cuidado quanto à preocupação do analista quanto à fidedignidade das lembranças. A recordação na cena da transferência pode expressar o desejo de retirar da lembrança algo que seja relacionado à fantasia. Parece-nos que a preocupação de Freud quando se ocupa com o que é visto, ouvido e experimentado no período pré-histórico é recolher das lembranças a relação do sujeito com o seu desejo. É importante pensar o porquê de a lembrança resistir à amnésia, assim como a natureza dessa lembrança e o que ela tem que ver com o aparelho psíquico proposto por Freud.

A lembrança da infância de Goethe que resistiu à amnésia foi discutida em sua autobiografia: Memórias, poesia e verdade (1811). Goethe, quando perguntado sobre a lembrança do nascimento de seu irmão, diz se lembrar de pegar algumas louças e jogá-las para fora da casa. Esse gesto, segundo Freud, significava uma ação simbólica em atirar para fora o novo bebê de sua mãe. Esse tipo de lembrança encobridora foi observado em outros pacientes de Freud. A aparente coincidência da travessura semelhante em crianças que ganharam um irmãozinho, segundo Freud, demonstra que talvez essa lembrança tenha resistido à amnésia pelo valor simbólico de jogar para fora algo que não se quer. Podemos propor que foi um resto psíquico que permaneceu na memória de Goethe. Freud afirma: 
Por regra geral resulta justamente, que a recordação que o analisando antecede, a primeira a que ele se refere, aquela com a qual introduz a sua biografia, demonstra ser a mais importante, a que oculta dentro de si a chave dos armários secretos de sua vida anímica (Freud 1917, 143).

Voltando à forma de ausência apontada por Merleau-Ponty, apesar de ser pouco provável que ele conhecesse a obra de Benjamin nessa época, não deixa de soar uma proximidade clara entre ambos, ao menos nesse ponto. Basta lembrarmos da passagem que encontramos nas últimas linhas da Fenomenologia da percep̧̧ão (1945): "assumindo um presente, eu retomo e transformo meu passado, eu mudo seu sentido, libero-me dele, desembaraço-me dele" (Merleau-Ponty 1967, 519). Ou ainda, essa passagem de Benjamin: "Sabemos que Proust não descreveu em sua obra uma vida como ela de fato foi, e sim uma vida lembrada por quem a viveu" (Benjamin 1994, 37). É isso que nos lembra Paula Sibilia ao comentar Proust:

Ele faz uma escavação nas camadas geológicas do seu eu passado, para resgatar todo esse universo íntimo a fim de recriá-lo em seu presente como uma obra de arte fictícia. Assim, preenchendo com a pluma milhares de páginas, Proust pintou todas as ruínas e os tesouros de sua Roma particular [lembrando da metáfora de Freud] (Sibilia 2016, 178).

O que vemos é: não há sentido em buscar uma verificabilidade entre o que se lembra e o que de fato "poderia ter ocorrido", mas o que vale para a pessoa como real em suas reconstruções, ressignificações. $O$ sentido que o passado tem para nós não é o passado como foi vivido, mas como o tomamos no presente ( $C f$. Merleau-Ponty 1967, 84). Lembremos de Freud: "Nossas lembranças infantis nos mostram nossos primeiros anos não como eles foram, mas tal como aparecem nos períodos posteriores em que as lembranças foram despertadas" (Freud 1996, 304).

A história pensada a partir da psicanálise, é vivida enquanto memória performativa: uma instauração de uma nova realidade a partir de uma ressignificação do passado. Poder-se-ia, aliás, acompanhar Merleau-Ponty quando ele nos diz que há uma deformação do passado: "deformo meu passado evocando o presente, mas dessas deformações, posso ter em conta que elas me são indicadas pela tensão que subsiste entre o passado abolido que viso e minhas interpretações arbitrárias" (Merleau-Ponty 1967, 389). Lacan repete isso quase com as mesmas palavras:

A história não é o passado. A história mostrou que isso não era tão simples. A história é o passado na medida em que é historicizado no presente - historicizado no presente porque ele foi vivido no passado. [...] o fato de que o sujeito revive, se rememora, no sentido intuitivo da palavra, os eventos formadores de sua existência, não é em si mesmo de tal importância. O que conta, é que ele o reconstrói. [...] Diria - no fim das contas, o que se trata, é menos de lembrar que de recriar a história.

(Lacan 1975, 19-20). 
Poderíamos pensar assim: o sujeito sempre será interrogado pelo enigma da morte; por sua vez, a escrita da experiência também diz respeito a um destino estético para tais experiências, numa vida que vale a pena ser contada. Por isso, poderíamos concluir com Christian Dunker:

Daí surge o impulso para o nascimento do gênero biográfico e autobiográfico. Uma vida que sirva ao mesmo tempo de exemplo e que inclua em si a própria atividade de narrá-la. Isso é tributário do cultivo, principalmente entre os estóicos, da escrita de si (Dunker 2011, 221).

Temos, assim, uma incidência importante de mais um dos traços formadores da noção de experiência: a escrita. A escrita memorialística apresentase sob o signo negativo, ou seja, relacionado a um sofrimento de uma perda ou uma ausência, como o luto de um objeto perdido ou o inapreensível de um evento traumático, bem como pelo signo positivo de um acontecimento de elaboração ou reconstrução.

É pensando nessa concepção de memória, reconstrução, ato performativo etc., que é intrigante imaginar o que lemos em uma autobiografia. Pensemos, primeiramente, o que a caracteriza.

\section{A AUtobiografia}

Tradicionalmente, o traço central de uma autobiografia é que o autor, o narrador da história e o personagem são o mesmo. O narrador conta suas memórias (do autor) tendo a si como personagem. A história é normalmente contada em primeira pessoa e as histórias narradas seriam "verídicas". $\mathrm{Na}$ verdade, o que garante a "verdade" da história

é a assinatura do autor. Mas, pensando nessa ideia de reconstrução, seria isso possível?

Em um livro recente, Sobre o declinio da 'sinceridade' - Filosofia e autobiografia de Jean-Jacques Rousseau a W alter Benjamin (2006), Carla Milani Damião diz: "Sendo o 'eu' uma criação, o compromisso de sinceridade do escritor com o leitor ou a transparência dessa relação por meio de uma narrativa que pretende ser verdadeira pode perder-se, e este é o risco que correria todo autor de memórias" (Damião 2006, 150). O que aconteceu, afinal, com a sinceridade no discurso autobiográfico?

É certo que a ideia de autobiografia se modificou profundamente desde As confissões de Santo Agostinho até a contemporaneidade. O sujeito moderno, tal como demonstrou Benjamin, tornou-se pobre em experiências comunicáveis. Uma perda da qual o sujeito jamais escapou, tornou-se privado de sua biografia. Lacan partilha essa ideia:

Não se trata de saber se falo de mim, de conformidade com aquilo que sou, mas se, quando falo de mim, sou idêntico àquele de quem falo. E não há aqui nenhum inconveniente em fazer intervir o termo 'pensamento'. Pois Freud designa por esse termo os elementos que estão em jogo no inconsciente, isto é, nos mecanismos significantes que acabo de reconhecer nele. Nem por isso deixa de ser verdade que o cogito filosófico está no cerne dessa miragem que torna o homem moderno tão seguro de ser ele mesmo em suas incertezas a seu próprio respeito, até através da desconfiança que há muito aprendeu a praticar quanto às armadilhas do amor-próprio. (Lacan 1957, 520, grifo nosso). 
Agostinho, por exemplo, escreveu suas confissões tendo como interlocutor, ninguém menos que Deus. Tudo que diz, se direciona a Deus. Assim, dificilmente podemos acusar Agostinho de estar criando uma ficção ou distorcendo a realidade - ao menos intencionalmente. E isso o impediria de estar fazendo, no fundo, uma reconstrução de suas memórias, tal como propôs Freud? Aliás, isso nos mostra que há uma diferença quando se escreve uma autobiografia se pensarmos qual é o seu interlocutor: a sociedade; um amigo; um padre; um analista etc. Sem contar que a forma de escrita de uma autobiografia se modificou profundamente desde então. Maria Rita Kehl, por exemplo, nos diz:

[...] o recurso à rememoração de modos de vida pré-modernos não é nostálgico, como pensariam alguns de seus críticos. Não se trata de dizer, melancolicamente, "antes é que era bom", e sim de fazer lembrar que o mundo "já foi diferente" - portanto, ainda pode mudar. Daí decorre a aparente nostalgia sugerida em alguns textos de Walter Benjamin [...] Se quiserem, podemos discutir ao final, o modo como este autor entende a modernidade, inspirado na poesia de Baudelaire, como um tempo que é sempre igual a si mesmo, portanto não apresenta nenhuma perspectiva de transformação no horizonte. Esta é a melancolia moderna: viver diante de uma eterna perspectiva de "mais do mesmo" - repetição que não produz diferença. "Que tudo fique como está, esta é a catástrofe", escreve ele num dos ensaios sobre a melancolia em Baudelaire (Kehl 2014, 115, grifo nosso).

Nas Confissões de Rousseau, por exemplo, ele iniciava dizendo que é a sinceridade o que guia toda sua escrita. Ser fiel na escrita ao que ele vivenciou e que consegue lembrar (contando inclusive o que ele se envergonha de lembrar). Mas se nos determos às suas ideias, vemos que ele defende que essa sinceridade se limita a uma lealdade à fala, devido a uma impossibilidade de veracidade que ele mesmo "confessa" não poder dar. Em outras palavras, assume que sua escrita é uma ficção e não uma mentira. Memória e imaginação já se filiam, de certa forma, nas confissões de Rousseau. Uma ideia que tornou forma na psicanálise, principalmente devido a Jeremy Bentham, o que levou Jacque Lacan a pensar que a verdade tem estrutura de ficção: “[...] a verdade, na medida em que seu lugar não poderia ser aquele em que se produz a fala, a verdade por essência [...] tem a estrutura de ficção" (Lacan 2006, 190).

Podemos dizer que desde 1899 Freud aponta para a memória enquanto uma construção. Nesse momento, em Lembranças encobridoras, Freud a compara com uma "obra de ficção". Ao analisar cenas infantis de um relato clínico, ele chega a essa conclusão (respondendo a um interlocutor, que hoje sabemos ser ele mesmo, sobre a possível combinações de fantasias na memória): 
Sim. Você projetou as duas fantasias uma na outra e fez delas uma lembrança infantil. $\mathrm{O}$ elemento das flores alpinas [usada na descrição] constitui, por assim dizer, um selo indicando a data da fabricação. Posso garantir-lhe que as pessoas muitas vezes constroem essas coisas inconscientemente - quase como obras de ficção. [O suposto analisando diz:] - Mas, se é assim, não houve nenhuma lembrança infantil, apenas uma fantasia recolocada na infância. No entanto, sinto que a cena é autêntica. Como se explica isso? [Freud novamente, mas agora como o interlocutor na posição de analista:] Em geral, não há nenhuma garantia quanto aos dados produzidos por nossa memória. Mas estou pronto a concordar com você em que a cena é autêntica. Nesse caso, você a selecionou dentre inúmeras outras da mesma espécie ou não, porque graças a seu conteúdo (em si mesmo irrelevante), ela se prestava bem para representar as duas fantasias, tão importantes para você. Uma recordação como essa, cujo valor reside no fato de representar na memória impressões e pensamentos de uma data posterior cujo conteúdo está ligado a ela por elos simbólicos ou semelhantes, pode perfeitamente ser chamada de 'lembranças encobridoras' (Freud 1996, 298).

Eis como Freud associa a memória com uma obra de ficção. Lembrando que toda ficção tem um "grão de verdade" (assim como em toda fantasia há uma correlação com algum traço mnêmico). Ou seja, nenhuma lembrança é completamente sem correlação ao que foi acontecido - há sempre um traço de verdade. Freud continua sua explicação sobre a fantasia em uma lembrança encobridora:

\begin{abstract}
Mas suponha agora que isso [que toda fantasia suprimida tende a deslizar para uma cena infantil] não possa ocorrer, a menos que haja um traço mnêmico cujo conteúdo ofereça à fantasia um ponto de contato - como se andasse meio caminho até ela. Uma vez encontrado um ponto de contato desse tipo [...], o conteúdo remanescente da fantasia é remodelado com a ajuda de todos os pensamentos intermediários legítimos [...], até que possa encontrar outros pontos de contato com o conteúdo da cena infantil. É muito possível que, no decorrer desse processo, a própria cena infantil também sofra mudanças; considero certo que também é possível promover falsificações da memória dessa maneira. No seu caso [no caso descrito com um interlocutor], a cena infantil parece apenas ter tido algumas de suas linhas gravadas mais profundamente [...]. Mas a matériaprima era utilizável. Não fosse por isso, não teria sido possível que essa lembrança particular, em vez de quaisquer outras, ganhasse acesso à consciência. Nenhuma cena desse tipo lhe teria ocorrido como uma lembrança infantil, ou talvez lhe ocorresse alguma outra - pois você sabe como é fácil para nossa engenhosidade construir pontes de ligação entre dois pontos quaisquer. [...] Logo, a fantasia não coincide completamente com a cena infantil. Baseia-se nela apenas em certos pontos, e isso depõe a favor da autenticidade da lembrança infantil (Freud 1996, 300-301).
\end{abstract}

Nesse caso, o analisando julga estar sendo sincera sua fala, mesmo que tudo que diga se valha de deformações. Como disse, o que importa é que, para ele, vale como se fosse real.

Algo com outro teor, mas não tão distante, encontramos em Charles Baudelaire, quando afirma que parte de uma sinceridade artística (isto é, sem pretensão de verificabilidade); ou em André Gide, quando resolve publicar seu Diário, que parece ter mais em vista a apreciação pública de sua vida. Benjamim chamava isso de "legalidade de recordação" 
Gide, entretanto, escreve no dia 3 de janeiro de 1892 essa passagem: "pode-se dizer, portanto, isto, que vislumbro como uma sinceridade vertida (do artista): ele não deve narrar sua vida tal qual a viveu, mas vive-la tal como vai narrá-la". Ou seja, há uma relação intrínseca entre sinceridade, memória e ficção confessa na concepção de autobiografia na contemporaneidade.

Podemos, aliás, lembrar de várias formas de descrever nossas memórias. Damião, se baseando na obra de Miraux, faz essa lista:

- O diário: a grande diferença seria a imediacidade do relato, que não lidaria com a memória, mas com a escrita do dia-a-dia. Não haveria também um destinatário (exceções devem ser consideradas).

- Recordações (souvenirs): não é um projeto que visa 'dizer tudo' (tout dire). Informa sobre acontecimentos dos quais o autor foi testemunha. Existe uma certa confiança entre autor e leitor.

- Memórias (próximas do souvenir). O autor tem uma função de testemunha, ele não é central e funciona como uma espécie de cronista.

- Ensaios e caderno de anotações (essais e carnets): a etimologia da palavra ensaio é examinar, pesar, provar, conferindo um caráter especulativo ao relato, no qual a experiência do mundo transformar-se-ia em uma proposta universal. Exemplo de Essai encontra-se em Montaigne: relato de experiências, encontros, leituras, fornecendo ao leitor a crítica e a liberdade de interpretá-las. Baseia-se nos Carnets de Joubert (século XIX) e de Camus (século XX), como exemplos para a seguinte característica: relato que se funda em episódios da existência, dos quais se retiram preceitos, análises gerais, máximas e aforismos (Damião 2006, 31-32).

Além dessas possibilidades, há pelo menos mais duas modalidades que poderíamos acrescentar a essa lista: as confissões de Agostinho, Rousseau etc.; e os texto de testemunha propriamente ditos, em que o autor descreve um acontecimento a partir do que vivenciou, como no caso de Primo Levi e milhares de outras testemunha dos campos de concentração, por exemplo.

Esse último caso nos parece mais difícil de analisar, porque o problema aqui é, seguramente, a questão da verdade. O que foi vivenciado, é real; mas a forma que relatamos o que vivenciamos também o é? Daí porque o gênero mais difícil de ser contestado, a meu ver, é o do testemunho.

Quando Primo Levi escreve É isso um homem? (1947), passou-se anos até que acreditassem naquilo que ele testemunhou. Por que? A questão da verdade, aqui, deve ser repensada através do problema da história. Os próprios carrascos nazistas sabiam disso:

Seja qual for o fim desta guerra, a guerra contra vocês nós ganhamos; ninguém restará para dar testemunho, mas, mesmo que alguém escape, o mundo não lhe dará crédito. Talvez haja suspeitas, discussões, investigações de historiadores, mas não haverá certezas, porque destruiremos as provas junto com vocês. $E$ ainda que fiquem algumas provas e sobreviva alguém, as pessoas dirão que os fatos narrados são tão monstruosos que não merecem confiança: dirão que são exageros da propaganda aliada e acreditarão em nós, que negaremos tudo, e não em vocês. Nós é que ditaremos a história dos Lager.

(Wiesenthal In Levi 2004, 9). 
Jeanne Marie Gagnebin analisa esse fato nessas palavras:

Essa ausência radical de sepultura é o avesso concreto de uma outra ausência, aquela da palavra. Primo Levi insiste, desde as primeiras linhas de Os afogados e os sobreviventes, sobre a vontade nazista de destruir a possibilidade mesma de uma história dos campos. Eles deveriam se tornar duplamente inenarráveis: inenarráveis porque nada que pudesse lembrar sua existência subsistiria e porque, assim, a credibilidade dos sobreviventes seria nula. O pesadelo comum que assombra as noites dos prisioneiros no campo - retornar, enfim, à sua própria casa, sentar-se com os seus, começar a contar o horror já passado e ainda vivo e notar, então, com desespero, que os entes queridos se levantam e se se vão porque eles não querem nem escutar e nem crer nessa narrativa -, esse pesadelo torna-se cruelmente real logo após a saída dos campos e quanta anos mais tarde. (Gagnebin 2009, 46).

A própria necessidade de Levi dizer ter de escrever e relatar o que vivenciou já é uma forma de reconstrução dos terrores que ele vivenciou. Longe de questionar a veracidade de suas histórias, o que quero dizer é que toda narração de uma memória se vale de reconstruções. O que ele nos traz já é, inclusive, uma forma de ele conseguir lidar com essa tragédia que ele nos relata, pois toda vez que falamos sobre nosso passado, nós o ressignificamos.

Por outro lado, o homem moderno volta para a casa a noitinha extenuado por uma mixórdia de eventos divertidos ou maçantes, banais ou insólitos, agradáveis ou atrozes -entretanto, nenhum deles se tornou experiência ( $c f$. Agamben 2007, 8). Este cenário que Giorgio Agamben nos convida a entrar diz respeito à relação entre o sofrimento individual e o social. Algo próximo nos diz Dunker: "A experiência individual no sofrimento singular se expressa em falas únicas, de preferência em primeira pessoa. Por isso é importante jamais separar o sofrimento individual dos movimentos sociais que lhe deram origem" (Dunker 2015, 36).

Lembremos, aliás, que no trabalho com as histéricas, Freud havia reconhecido que o sofrimento delas tinha uma relação com aquilo que estava posto socialmente. Pensando sobre esse ponto, Vladimir Safatle faz uma contraposição entre a solidão com o social: ela é uma tentativa de resistir a "ter que ser um indivíduo" (Safatle apud Dunker 2015, 36). Entretanto, alguns pensadores destacam como há uma passagem importante entre o que é uma queixa de isolamento e as práticas de segregativas:

Obviamente há movimentos inibitórios que servem como tentativas de isolamento, de criação de um espaço de risco zero e protegido, buscando o velamento das dificuldades na relação do sujeito com os outros. Há ainda práticas segregativas advindas do Outro [de um "outro" que não é empírico, mas que supostamente nos pautamos], nas quais a solidão passa a ser uma condição forçada (Tatit; Rosa 2013, 137, grifo nosso).

Isso nos indica como a condição forçada da solidão mostra como o social produz uma linguagem própria em relação ao sofrimento. Diante da dificuldade de nomeação, da impossibilidade de representação do real, os sobreviventes da guerra voltavam silenciados; a partir disso, uma nova era se iniciou como nos indica novamente Dunker: "Uma era na qual as articulações entre mal-estar e sofrimento seriam reordenadas" (Dunker 2015, 25). 
Conhecemos como Primo Levi, depois de sobreviver ao horror da Segunda Guerra, volta para casa e tem um sonho recorrente: as pessoas bocejavam à mesa, na hora do jantar e se levantavam e não se interessavam pelo que ele tinha a dizer. Este fato, no testemunho de Levi, demonstra que mesmo de volta à casa, o outro estava ausente, porque somente há alguém quando esta escuta. Podemos lembrar de uma passagem de Freud que nos esclarece o que está em jogo aqui:

\begin{abstract}
Devo essa explicação sobre a origem do medo infantil a um garoto de três anos, que escutei falar, certa vez, de dentro de um cômodo escuro: 'Tia, fale comigo; tenho medo, porque está muito escuro'. A tia exclamou: 'De que adianta? Você não está me vendo'. Ao que o menino respondeu: 'Não importa, quando alguém fala, fica claro'. - Ou seja, ele não tinha medo por causa da escuridão, mas porque sentia a falta de uma pessoa amada, e podia afirmar que se tranquilizaria tão logo obtivesse uma prova da presença dela (Freud 2016, 146).
\end{abstract}

Não há forma mais clara de mostrar que a palavra traz uma outra forma de presença que não é da ordem da imagem - do imaginário -, mas da ausência. Afinal, a voz da tia, no escuro, reconhecia o medo da criança. O medo de não ter o sofrimento reconhecido é tão nefasto quanto à impossibilidade de nomeação do mal-estar. Para Levi, o lugar onde poderia surgir o conforto, o apaziguamento da angústia, insistiu em ser, nos seus sonhos, um lugar silencioso e solitário.

Importante notar que o trabalho como testemunha de Levi não é vingativo, mas uma narração que ressignifica o que ele vivenciou, diferentemente das experiências de ressentimento que vemos em muitos relatos autobiográficos. Lembremos, por exemplo, do livro Ressentimento (2004) de Maria Rita Kehl. Em um dado momento, ela observa que a incapacidade de esquecimento na filosofia de Nietzsche é o agravo do ressentido - como se a memória fosse uma doença. Por isso irá afirmar que mais vale viver em uma ilusão do que buscar uma suposta verdade que diminua a potência vital. Em sua Segunda consideração intempestiva Da utilidade e desvantagem da história para a vida, Nietzsche afirma que o homem deve aprender a esquecer para poder viver: "[...] dito de maneira mais erudita, a faculdade de sentir a-historicamente durante a sua duração" (Nietzsche 2003, 9). Não esquecemos exatamente aquilo que nos tira a potência de viver - o que nos marca e não cessa de doer. O que Nietzsche propõe é:

[...] que se saiba mesmo tão bem esquecer no tempo certo quanto lembrar no tempo certo; que se pressinta com um poderoso instinto quando é necessário sentir de modo histórico, quando de modo a-histórico. Esta é justamente a sentença que o leitor está convidado a considerar: o bistórico e o a-histórico são na mesma medida necessários para a saúde de um indivíduo, um povo e uma cultura (Nietzsche 2003, 11).

Assim, viver no ressentimento seria viver ruminando silenciosamente alguma vingança: vingar de um outro que supostamente é a causa de seu sofrimento; ser incapaz de superar o passado:

o ressentido é um escravo de sua impossibilidade de esquecer. Vive em função de sua vingança adiada, de modo que em sua vida não é possível abrir lugar para o novo. Mas como se trata de um vingativo passivo, seu silêncio acusador e suas queixas contínuas mobilizam, no outro, confusos sentimentos de culpa (Kehl 2004, 91). 
Muito distante disso estão os escritos de Levi. Ele mesmo afirma que a sua insistência em dar testemunho de Auschwitz se dá para que esse passado jamais se repita - algo que também está no horizonte de pensamento de Benjamin. Como analisa Gagnebin: "[...] ele precisa transmitir o inenarrável, manter viva a memória dos sem-nomes [...] lutar contra o esquecimento e a denegação é também lutar contra a repetição do horror (que, infelizmente, se reproduz constantemente)" (Gagnebin In Benjamin 1987, 47). Como se o trabalho de Levi fosse de cuidar da memória dos que não podem falar - e essa história contada pode trazer a potencialidade de transformar nosso presente.

Pensemos um outro exemplo. "Escrevi apenas aquilo de que me lembrava" é a bela forma que Natalia Ginzburg encontrou para se desculpar das lacunas em seu livro Léxico familiar. Sua sinceridade transborda a ponto de não alterar os nomes e os fatos de suas lembranças - um texto baseado no ato de recordar. Ginzburg, sobrevivente como Primo Levi, narra o mesmo acontecimento de forma diferente. Nesse romance autobiográfico e em outros ensaios, ela calcula a forma como contava as histórias, fazendo-as mais curtas, a fim de ser escutada pelos irmãos mais velhos, impacientes. Assim, escreveu para entrar nos diálogos, para incluir o outro, num exercício de com memorar. Assim, a escrita de si, que por vezes pode ser tomada como narcísica ou solitária, ainda assim, preserva a possibilidade de um interlocutor e um leitor. Mas, onde estaria o "si mesmo", afinal? Natalia faz de sua escrita uma experiência de reconstituição de uma experiência, sem ressentimento ou tristeza, ela procura reconstituir sua experiência. As casas em ruínas, não são abandonadas ou esquecidas para serem reencontradas, como Pompéia. Elas adquirem valor justamente por serem ruínas e pedras; pedras com nomes, preciosas, em uma memória reconstruída pela linguagem: "Nós não podemos mentir nos livros, nem podemos mentir em nenhuma coisa que fazemos. E talvez este seja o único bem que nos veio da guerra. Não mentir e não tolerar que os outros mintam em nós" (Ginzburg 2020, 64). Mas o paradoxo acerca da veracidade da memória não é desconsiderado pela autora em outro momento: "A memória é lábil, e porque os livros extraídos da realidade frequentemente não passam de tênues vislumbres e estilhaços de tudo o que vimos e ouvimos" (Ginzburg 2018, 16).

Isso nos diz que há coisas que devem ser rememoradas, não porque diminui nossa potência de vida, mas porque o passado ainda traz uma potencialidade que não foi devidamente desenvolvida. Daí o interesse pela história marginal como nos diz Gagnebin:

\begin{abstract}
Esse narrador sucateiro [...] não tem por alvo recolher os grandes feitos. Deve muito mais apanhar tudo aquilo que é deixado de lado como algo que não tem significação, algo que parece não nem importância nem sentido, algo com que a história oficial não sabe o que fazer. [...] Ou ainda: o narrador e o historiador deveriam transmitir o que a tradição, oficial ou dominante, justamente não recorda. [...] pois não se trata somente de não se esquecer do passado, mas também de agir sobre o presente. A fidelidade ao passado, não sendo um fim em si, visa à transformação do presente (Gagnebin 2009, 54-55).
\end{abstract}

Freud, em seus primeiros trabalhos, tem uma concepção de cura que nos interessa aqui. Pensando na histeria, ele pensa que a conversão de um afeto no corpo pode ser revertida se esse afeto "encontrar" seu conteúdo/sua representação adequada e for "expresso". Nesse sentido, podemos entender por que Freud e Breuer dizem, em seu texto conjunto (Sobre o mecanismo psíquico dos fenômenos bistéricos de 1893), nesse momento, que o histérico sofre sobretudo de reminiscências ( $c f$. Freud; Breuer 2016, 25). Ora, o sujeito sofre por algo que 
aconteceu; e o afeto vivido, por não ter tido uma cisão com sua representação, converge ao corpo. É pensando nisso que Osmyr Faria Gabi Jr. escreve: para Freud, "[...] o principal traço do patológico está na indistinção estabelecida entre recordação e percepção, ou seja, a doença mental é caracterizada como sendo basicamente alucinação" (Gabbi Jr. 2003, 53). Gabbi Jr. insiste nessa questão da reminiscência: "A aproximação feita com a liberação sexual indica que não é propriamente a vivência dolorosa que seria o protótipo do patológico, mas sua recordação" (Gabbi Jr. 2003, 59).

Freud retoma essa questão da reminiscência posteriormente, também pensando na ideia de cura. Ele afirma, por exemplo:

Seria abandonado o esforço vão de convencer o doente de que seu delírio é louco e contradiz a realidade, e se buscaria encontrar, reconhecendo o núcleo de verdade, um ponto em comum sobre o qual se desenvolvesse o trabalho terapêutico. Esse trabalho consistiria em liberar o quê de verdade histórica [cf. Freud 2018, 179] de suas deformações e seus apoios na realidade presente e ajustá-lo ao lugar do passado a que pertence (Freud 2018, 342).

Eis como Freud tem agora em mãos "traços" de uma outra concepção de verdade em vista: uma verdade que aparece em forma de delírio. Daí porque ele conclui seu raciocínio com essas palavras que nos lembra de suas primeiras formulações sobre as histerias: "[...] também o delírio deve sua força persuasiva à parte de verdade histórica que põe no lugar da realidade rejeitada. Dessa maneira, também ao delírio se aplicaria a frase que um dia usei apenas para a histeria: que o doente sofre de suas reminiscências" (Freud 2018, 343). Ou seja, o trabalho da análise seria superar essas reminiscências. Não negando o passado, mas o ressignificando.

Resumidamente, podemos dizer: o que nós tomamos enquanto realidade, nossa relação com o mundo, conosco, com os outros e com a nossa história é uma construção psíquica sem qualquer necessidade de relação com a realidade que podemos chamar de "material". Em outras palavras, não há uma pretensão de verificabilidade quando alguém conta uma história. O que a pessoa nos conta é uma realidade para ela, mesmo que não tenha nenhuma conexão ao que supostamente aconteceu. Por exemplo: duas pessoas podem contar sobre um mesmo acontecimento sem que haja uma conexão lógica entre as histórias contadas. O que é real para a pessoa é como o que foi vivido é ressignificado ao contar essa história - vale como se fosse real sua fala. Assim, trata-se de uma verdade que se ressignifica na própria experiência de vida - a todo momento damos um novo sentido à nossa história, sem que se trate de um ato de má-fé, mentira ou fingimento - é, literalmente, o que vale como real para a pessoa.

A importância da veracidade da fala ao narrar uma história é tão fundamental, que alguns pensadores, como Giorgio Agamben, chegam a pensar na origem da linguagem a partir da ideia de testemunha/juramento. Ou seja, os homens, por serem infiéis, não tem credibilidade em sua fala. Para que um relato seja confiável, é preciso um juramento. E esse juramento só é possível porque é testemunhado por Deus. Sendo assim, a narração de uma história só pode ser crível porque Deus testemunha a fala do orador. Dizer uma mentira sob a testemunha de Deus, seria uma maldição; dizer algo sem que tenha um juramento, é simplesmente uma blasfêmia. Quer dizer, o que garante a fala é a testemunha de Deus. 
Sobre a maldição, diz Agamben:

O que a maldição sanciona é o fato de não ocorrer a correspondência entre as palavras e as coisas que estão em jogo no juramento. Quando se rompe o nexo que une a linguagem e o mundo, o nome de Deus, que expressa e garantia essa conexão 'bem-dizente', torna-se o nome da 'mal-dição', a saber, de uma palavra que rompe a sua relação verídica com as coisas (Agamben 2011, 52).

A dificuldade da questão para Agamben é que o juramento torna possível que vida e linguagem se correspondam. É o nexo entre ações e palavras que nos tornam humanos. Mas o que acontece quando a humanidade já não dá mais crédito à fala - já a toma como um perjúrio, por ser incapaz de ser juramentada?

\section{A FORMA DiÁRIO}

Quando lemos uma autobiografia, a única credibilidade da fala é a assinatura do autor. Daí porque Agamben destaca a partir de Prodi, que "[...] somos hoje as primeiras gerações que vivem a própria vida coletiva sem o vínculo do juramento [...]" (Agamben 2011, 81). Isso explicaria, em larga medida, o desinteresse que temos pelas autobiografias e preferimos a forma "diário", pois o relato diário de acontecimentos parece mais fidedigno. $\mathrm{Na}$ verdade, uma transformação que acompanha a ascensão da credibilidade na informação (algo que supostamente tem uma verificabilidade imediata e não é necessária uma interpretação) e não mais na narrativa (o que exige uma interpretação e, por isso, pode estar sujeita ao "engano"). Agamben nos diz sobre isso:

\footnotetext{
Por um lado, o ser vivo agora está, cada vez mais reduzido a uma realidade puramente biológica e à vida nua, e, por outro, o ser que fala, separado artificiosamente dele, por uma multiplicidade de dispositivos técnicosmidiáticos, em que a experiência da palavra cada vez mais vã, pela qual é impossível responder e na qual algo parecido com uma experiência política se torna cada vez mais precário (Agamben 2011, 81).
}

É sobre essa nova forma de ser do homem, que privilegia as informações que gostaríamos de debater. Como observa Damião, há uma perda de interesse pela autobiografia:

O diário particular ou íntimo tende a se tornar o gênero favorito do século $\mathrm{XX}$, o que ocorre por dois motivos: uma vontade de manifestação de sinceridade e um desprezo pela literatura. [...] A falaciosa afirmação de que 'os fatos falam por si mesmos' passa a ser assegurada pelo jornalismo, que não só rejeita a autobiografia, pela incerteza do relato, como afasta o romance, por seu arcabouço fantasioso. [...] Há também um gosto pelo fragmentário, pelo inacabado (Damião 2006, 69).

Podemos pensar essa transformação a partir de um estudo de David Harvey denominado Condição Pós-Moderna (1989). Harvey busca, nessa obra, mostrar as transformações que ocorreram na passagem da modernidade ao que ele nomeia pós-modernidade. Ele destaca as transformações na cultura, na área político-econômica e na experiência que temos do espaço e do tempo. Interessame essa última transformação nessa reflexão. 
O que Harvey destaca é uma transformação em nossa forma de vivenciar o espaço e o tempo na contemporaneidade. É como se o tempo e o espaço tivessem perdido sua "profundidade" e fosse vivida agora somente em sua imediaticidade. Vivemos em um mundo que exige o presente; que não tolera a frustração. "Afinal, a modernização envolve a disrupção perpétua dos ritmos espaciais e temporais, e o modernismo tem como uma de suas missões a produção de novos sentidos para o espaço e o tempo num mundo de enfermidade e fragmentação" (Harvey 2001, 199).

O culto da enfermidade e fragmentação, da imediaticidade, constituem nossa nova forma de ser: no trabalho, no lazer, no desejo, na linguagem etc. É isso que vemos de forma mais clara se pensarmos em relação à concepção de informação na contemporaneidade:

\begin{abstract}
A forma de transmissão das informações é também acrônica porque não indica as causas de um acontecimento, como se algo acontecesse fora de situação, sem qualquer história, como se um crime fosse cometido, por exemplo, sem ter causas sociais, políticas, culturais e históricas envolvidas. Assim, a informação é dada de forma unicamente pontual - sem história, e, consequentemente, sem consequências, sendo válido somente no presente. É como se o espetáculo televisivo buscasse apagar a memória e a capacidade de reflexão futura - a única coisa que interessa é o que é dado 'no agora'. [...] Resultado: temos uma ilusão de informação! Temos a ilusão de estarmos muito bem sabidos sobre todas as coisas que estão acontecendo pelo mundo e isso de forma rápida e fácil - basta que não percamos os noticiários diários. Tamanha é a ilusão que torna as pessoas suficientemente capazes de repetir o que acham de todos os acontecimentos, porque depois de ter visto as imagens e escutado alguém 'competente' fazer um comentário sobre o que foi apresentado, incorporamos a fala da pessoa competente e dizemos agora "em nome" da verdade. Sendo assim, o critério que temos para saber da veracidade de um fato é a credibilidade que damos ao noticiário e ao âncora e/ou comentador do programa, mesmo desconhecendo as causas do porquê do acontecimento, ou sabendo de forma lacunar sobre o caso, simplesmente tomamos como crível 'que deve ser assim'. Temos, portanto, uma ausência de referência de tempo e espaço, afinal, da história. As notícias são dadas de forma rápida, mínima e inexata, sem contexto, sem história - só um fato bruto [...] (Manzi 2019, 78-80, grifo nosso).
\end{abstract}

Poderíamos, aliás, vislumbrar essa mudança brusca de nossa relação com o espaço e tempo se tomarmos a tese número 200 de Guy Debord em $A$ sociedade do espetáculo (1967). Nessa famosa passagem, Debord nos diz sobre um "grande aparelho técnico de difusão de imagens"; que os homens de sua época não vivem os acontecimentos. Conclui com essa passagem: "É porque a história ela mesma assombra a sociedade moderna como um espectro, que encontramos da pseudohistória construída em todos os níveis da consumação da vida, para preservar o equilíbrio ameaçado do atual tempo congelado" (Debord 1992, 192). Ou seja, vivemos em um tempo congelado, em que a única coisa que conta é o presente, o instantâneo, como se o passado só valesse como "espectro".

Eis porque a concepção freudiana de reconstrução do passado, de ressignificação, ou a concepção de memória performativa se perde na contemporaneidade para uma concepção de tempo congelado; de um passado místico, porque não nos atinge; de uma sucessão de tempo. A forma mais clara dessa sucessão de tempo se dá na forma diário que encontramos nas redes sociais, em que todos os dias as pessoas postam o que fizeram, onde foram etc. Ou na escrita de diários de celebridades - a forma diário, por ser escrita dia a dia, parece mais com o "espírito" do imediato: o que pensei e fiz hoje. A vida como um álbum fotográfico; a sensação que se tem é que o passado não é mais 
válido; lembramos dele com nostalgia: passado como passado e não como algo que se ressignifica no nosso tempo.

Os álbuns de fotografias nos lembram do que um dia Merleau-Ponty criticou dos museus. A seu ver, o que uma obra de arte nos traz é um passado da própria história de arte que é ressignificado em uma nova pintura. Uma ressignificação, uma vez que se propõe um novo estilo. Assim, os museus seriam, em certa medida, "corruptores" dessa reativação do sentido pois,

\footnotetext{
Enquanto que o estilo em cada pintura viveu como a pulsação de seu coração e lhe tornou justamente capaz de reconhecer todo outro esforço que o seu, - o Museu converteu essa historicidade secreta, pudica, não deliberada, involuntária, vivente enfim, em história oficial e pomposa (Merleau-Ponty 2000, 78).
}

Como se o passado não mais trouxesse uma potencialidade. Ou, como diz Paula Sibilia: "[...] o passado ficou incapacitado para conceder inteligibilidade ao caótico fluir do tempo, e também se tornou incapaz de explicar o presente e a mítica singularidade do eu" (Sibilia 2016, 164).

Paula Sibilia publica em 2008, O show do Eu - A intimidade como espetáculo. Esse livro é importante em nosso tema, porque descreve como a forma diário se modificou. Antes, um diário era guardado a sete chaves (uma intimidade inviolável); na contemporaneidade, fazemos a exposição de nossa intimidade. De uma vida privada, passamos a uma vida pública. Ou seja, todos nós podemos agora expor nossa intimidade; não só isso, expomo-nos e esperamos que as pessoas "curtam" (uma aprovação social que se baseada em "curtidas", compartilhamentos, quantidade de seguidores). Daí porque não é estranha uma inversão; por exemplo, um político passa a divulgar sua vida pessoal para ser notado no espaço público: posta a si como um bom pai; bom marido; bom amigo; como uma pessoa dinâmica; jovem etc. - literalmente se promove pela sua imagem privada no espaço público. Mesmo que seja incompetente de ocupar um cargo público, sua imagem vale mais do que sua suposta "competência" (queremos saber da "vida real" do político - isso parece ser mais importante do que ele propõe).

O que está por trás disso é uma nova forma de pensar a subjetividade não mais aquela subjetividade que se fechava em seu quarto para escrever um diário ou para ler um romance, mas que investe em si, em sua imagem, e quer imediatamente um retorno por esse empreendimento de si. Por isso, a melhor forma de se expor é a imediaticidade de imagens e não uma autobiografia em que não se tem nem mesmo "confiabilidade". A imagem, por outro lado, "diz tudo"; não mente!

Façamos, entretanto, um contraponto. Por um lado, uma escrita de um diário que nos remete à ideia de experiência; por outro lado, que nos leva a pensar numa "sinceridade performativa". O primeiro exemplo é o que encontramos, por exemplo, na publicação de Quarto de despejo de Carolina Maria de Jesus. Com uma escrita "que lhe sangra", tal como a de Ginzburg, Carolina está às voltas com a falta, não no sentido de uma ausência, mas de uma dor de existir ou de uma perda sob a forma da fome. O diário de uma favelada (subtítulo do livro) foi um dos livros a ser apreendidos pelo Dops, no regime militar, considerado subversivo por sua crítica social. É isso que nos diz Marise Hansen: 


\begin{abstract}
Mas entender a palavra como alimento, no caso de Carolina, leva à reflexão sobre a premência de escrever, o alcance do papel da literatura, que, afinal, pode garantir-lhe outra forma de existência e de fala. A palavra, portanto, não só tem papel paliativo por ser desabafo solitário e alívio para a angústia, mas guarda a "potência de poder" de vir a público e tornar-se vOz no campo literário, o que pressupõe eternização (uma vez que é escrita) e instrumento de denúncia (Hansen 2020, 29).
\end{abstract}

A vida privada na intimidade do barraco na favela, se transforma numa escrita que busca uma saída: "6 de agosto, fiz café para João e José Carlos que hoje completa 10 anos. E eu apenas posso lhe dar os parabéns, porque hoje nem sei se vamos comer" (Jesus 2014, 106).

Por outro lado, podemos destacar como vivemos em um mundo em rede, em que a visibilidade se tornou o alvo central nas relações interpessoais. As redes sociais incentivaram essa visibilidade, inclusive pagando aos consumidores que mais são assistidos, incluindo propagandas nos acessos. Enfim, criou-se uma nova profissão (celebridade da internet) ao tornar alguns jovens milionários por exporem sua vida diariamente ("não se lava mais roupa suja em casa", diríamos, mas na frente das câmaras, com milhares de espectadores). Quer dizer, vivemos uma nova forma de vida baseada na mídia e no mercado - em que naturalizamos essa forma de ser; e somos incentivados a ser a celebridade do momento:

Gerou-se, assim, um verdadeiro festival de vidas privadas que oferecem despudoradamente aos olhares do mundo inteiro. As confissões diárias de você, eu e todos nós estão aí, em palavras e imagens, à disposição de quem quiser bisbilhotá-las. Para isso, basta apenas um clique do mouse; e, de fato, tanto você como eu e todos nós costumamos dar esse passo (Sibilia 2016, 52).

Passamos de uma subjetividade "interiorizada" para o que Sibilia denomina show do eu. Isso modifica bastante a forma de pensarmos o homem; não mais aquele homem que se fecha no quarto para ler intermináveis páginas em total concentração, para pessoas que não suportam mais ler, senão através de imagens - como se a imagem revelasse toda a verdade do eu, num instante que é apreendido pela câmera. Assim como os pequenos comentários da vida cotidiana, que não ultrapassam meia dúzia de frases: "A vida real, então, é convidada a performar e a se realizar em cena: de preferência, na visibilidade das telas" (Sibilia 2016, 249). Cuidar de si, nesse contexto, é cuidar de sua imagem: "para se fortalecer [o eu] e para constatar a sua existência, portanto, ele deve tornar-se visível e compartilhar a sua vida nas vitrines do mundo" (Sibilia 2016, 286). Essa nova realidade parece mais convincente e inclui todos: nós podemos virar espectadores e celebridades. Assim,

[...] as atividades em grupo são tidas como mais criativas e produtivas do que o clássico trabalho individual em solitária concentração. E a capacidade de fazer várias coisas ao mesmo tempo é mais estimulada e premiada que a habilidade de focar a atenção numa tarefa contínua e persistente. A abrangência inédita desse tipo de mudanças socioculturais pode levar, inclusive, a questionar se o transtorno de déficit de atenção e hiperatividade, conhecida como $\mathrm{TDA} / \mathrm{H}$, não seria mais bem compreendido como um traço característico das novas subjetividades perfeitamente compatível com o mundo em que vivemos, e até mesmo por ele incitado -, em vez de uma estranha epidemia infantil.

(Sibilia 2016, 78). 
Cuidar da imagem de si para os expectadores acompanha perfeitamente a mudança do privado ao público. Isto é, o que vemos é uma performance de si no espaço público. Ou, em outros termos, há uma conquista da visibilidade pública da vida privada, como se fizéssemos da confissão o valor maior de nossa sociedade - a pretensão de mostrar "tudo", de forma imediata e sem cortes; como se vivêssemos em uma casa de vidros e fizéssemos uma autopromoção constante (uma forma de "tirania da visibilidade"). "O luxo estava nas coisas; de agora em diante, ele está no indivíduo. [...] ser apenas si mesmo" (Ehrenberg 2010, 37) - diz Alain Ehrenberg.

Isso está diretamente relacionado ao espírito empresarial de nossa época. Ehrenberg, por exemplo, escreve $O$ culto da performance - Da aventura empreendedora à depressão nervosa (1995). Ele parte da questão da performance:

[...] a única questão é que hoje o indivíduo comum não deve mais se acomodar com esses devaneios: exige-se dele que aceda verdadeiramente à individualidade por meio de uma passagem à ação. A democratização do aparecer não está mais limitada ao confortável consumo da vida privada: ela invadiu a vida pública sob o viés de uma performance que impulsionava cada um a se singularizar, tornando-se si mesmo (Ehrenberg 2010, 11).

Mas esse viés performativo é mais bem visualizado na figura do empreendedor - esse seria o modelo do herói que assume riscos, que busca desafios, que busca a vitória a qualquer preço em uma sociedade em que todos querem ser visualizados - em uma sociedade de concorrência.

É como se tivéssemos perdido qualquer referencial de ideal, sendo nós mesmos o único ideal - um indivíduo que governa a si mesmo; que tem vontade de ganhar; de ser herói de si mesmo (é essa a máxima visibilidade); de ser empresário da própria vida.

Hoje, cada um, independentemente de onde venha, deve realizar a façanha de tornar-se alguém por meio de sua própria singularização. Essa exigência implica não em uma identificação com um modelo superior estabelecido a priori, mas - com o pobre sendo livrado de uma indigência e o capitalista do capital - em forjar seu próprio modelo: ser bem-sucedido em ser alguém é empreender tornar-se si mesmo (Ehrenberg 1995, 172).

Poderíamos mesmo afirmar que entramos em um encantamento da vida cotidiana (a vida real, relatada em diários na rede), pois todos podem fazer de si um ideal e o modelo possível de autorrealização. Essa aventura estaria ao alcance de "todos", pois basta realizar uma espécie de pedagogia de si (ser único/autêntico). "Dizem-nos", afirma Ehrenberg, "que tudo é possível em todos os domínios de atividade, desde que se tenha vontade de ganhar" (Ehrenberg 1995, 48).

$\mathrm{E}$ o que isso significa esse valor mais celebrado: ser bem-sucedido? 
O que é ser bem-sucedido? Essa é uma questão que lembra uma outra: por que o sucesso se refere ao empreendedor? Ser bem-sucedido, hoje, é poder inventar seu próprio modelo, desenhar sua unicidade, ainda que idêntica à de todos os outros. Ser bem-sucedido é tornar-se si mesmo tornando-se alguém. Ser si mesmo, ser alguém: injunções banais e, no entanto, misteriosas que deveriam situar-se em registros aparentemente separados, até opostos, da identidade pessoal e da visibilidade social, da esfera privada e da esfera pública - como se sabe que se é si mesmo? Diante de quem se reconhece que se é alguém? Essas duas questões entram hoje numa relação inédita que assimila, numa mesma retórica, a conquista de sua identidade pessoal à de ascensão pública, a busca de autenticidade à da visibilidade. Dinâmica dupla de exteriorização do íntimo - isso seria sua 'publicização' - e de incorporação do social - isso seria sua 'privatização' - que forma a trama da ambição contemporânea (Ehrenberg 2010, 50).

Ser bem-sucedido é criar sua própria história, independentemente de qual classe social o indivíduo viva. Não há mais mérito em ser "filho de... x ou y"; é preciso criar sua própria identidade por suas ações: "essa ficção é aquela do indivíduo puro, que não tem outra referência e outra origem que não si mesmo, que é apenas o filho de suas próprias obras. É o sonho igualitário de hoje e é o desejo mesmo de ser sujeito" (Ehrenberg 1995, 72). Não por acaso, o discurso das pessoas bem-sucedidas é de autenticidade e influência: ser você mesmo; investir em si; ser sincero (fazer uma performance de si) - é isso o que lhe faz ser reconhecido. Há, assim, a reivindicação de sinceridade, de ser o mais "real" possível - algo que está muito próximo da confiabilidade das informações: o que pode ser verificável. Uma celebridade na internet é, curiosamente, uma espécie de artista sem obra: não importa exatamente o que você faz, mas o que supostamente é; é-se famoso por ser sincero e por mostrar sua vida "tal como ela é" e não por ter feito algo em específico.

A exposição do que supostamente é real é o que convoca a presença de infinitos programas confessionais, em que se entrevista a celebridade na casa dela, por exemplo, mostrando seu dia a dia. Ou o sucesso dos reality shows:

As estrelas do show business são os modelos de ação que nos fazem pensar que podemos todos ser nosso próprio modelo. Essas figuras são únicas, como todo mundo; somos todos únicos, como cada um dentre todos. Entre estes e nós, não há nenhuma superioridade, mas uma diferença de visibilidade (Ehrenberg 1995, 75).

Essa "diferença de visibilidade" é o fundamental: criar uma autoimagem é uma exigência de escolha de uma individualidade que seja invejável por outros - um ideal empresarial por excelência, pois na empresa, ser um empreendedor de suas próprias metas e tarefas, ser parceiro da empresa e não um simples funcionário que segue ordens, eis o que se torna um indivíduo bem-sucedido.

Não esqueçamos que o mais visível é o nosso corpo. É o que Maria Rita Kehl já nos alertava em seu texto Com que corpo eu vou?:

Que corpo você está usando ultimamente? Que corpo está representando você no mercado das trocas imaginárias? Que imagem você tem oferecido ao olhar alheio para garantir seu lugar no palco das visibilidades em que se transformou o espaço público no Brasil? Fique atento, pois o corpo que você usa e ostenta vai dizer quem você é (Kehl In Bucci; Kehl 2004, 174). 
Daí uma crença de nunca envelhecermos - de vivermos em um tempo congelado, um eterno presente.

Afinal, ser bem-sucedido; ser herói de si mesmo etc., - todos esses ideais participam de uma concepção de visibilidade que é contemporâneo da perda da narrativa: é preciso ser bem-sucedido a todo custo; é preciso entrar no que Sibilia denominou show do eu. Com essa mudança, a forma diário ("o que fiz hoje") é a mais bem-sucedida entre nós. Com isso, não mudamos somente da autobiografia ao diário, mas nossa forma de ver o mundo - do eu que narra a um eu que descreve; de um eu leitor a um eu receptor de imagens; etc.

Sendo assim, a memória pensada como ressignificação, reconstrução e memória performativa, dá lugar a um eu que é puro aparecer - a-histórico e atemporal; uma imagem a ser apreciada momentaneamente. Tal deslocamento acompanha a concepção de verdade enquanto verificabilidade, tal como se prega na ideia de informação. A forma diário ganha aqui seus contornos mais claros: cada dia é cada dia, sem ligação com um passado que possa nos transformar; um dia não tem relação necessária com outro, pois vivemos em um mundo fragmentado, instantâneo, em que tudo muda completamente. O que importa é o aqui e agora que é registrado a todo momento e não trabalhado, narrado, ressignificado. A metáfora arqueológica de Freud se desfaz para um presente contínuo: o que tem sentido é somente o que é visualizado no instante e se perde para outro instante, sem uma relação senão de fragmentos de um tempo presente. A ideia de uma busca de um tempo perdido se desfaz para "retalhos de instantes". O que está por trás disso é uma tese de que o passado perdeu toda sua potencialidade: é como se toda sua potencialidade já estivesse em ato, presente e, por isso, olharíamos para o passado como algo simplesmente distante, sem potência. O diário comprimindo passado e futuro, no "um dia de cada vez" nas dificuldades do mundo.

O que vemos é uma utopia de se pensar o cérebro como um arquivo de computador: vários dados que podem ser agrupados ou deletados quando quiser - como se exigíssemos que o passado não mais interferisse em nossa vida, tal como a lembrança de um casamento desfeito, de uma passagem da vida que não gostamos de lembrar. Ou seja, um cérebro em que pudéssemos escolher os arquivos que nos "interessam", eliminando tudo o que consideramos desagradável - mais ou menos como arrancar as páginas de um diário de coisas que arrependemos de termos escrito.

Quem não se lembra de Joel, personagem do filme Brilho Eterno de uma Mente sem lembranças (2004) que, apaixonado e abandonado, resolve contratar a empresa Lacuna para extrair de seu cérebro suas lembranças com a mulher amada e perdida? A ideia principal aqui é considerar a capacidade de esquecer, a fim de interromper o sofrimento. Isso nos diz algo fundamental: não é uma escolha querermos ou não esquecer de algo. Joel precisa se lembrar para esquecer, e nesse processo de recordação, se arrepende, pedindo para salvar as lembranças boas dos momentos felizes com Clementine. Assim, temos um paradoxo: precisamos lembrar para esquecer: encontramos o problema freudiano original acerca das relações entre o lembrar e o prazer/desprazer. Entre esquecer o desprazer e lembrar o prazer, como funciona a seletividade da memória? Essa é a pergunta que levará Freud a formular o recalcamento e a concepção do trauma. A dinâmica do lembrar, refere-se, portanto, à economia da lembrança, que ora serve ao desejo de esquecer, como no trabalho de luto, ora à necessidade de recordar. 
Gostaríamos de concluir lembrando do belo escrito de Benjamin denominado Comida: omelete de amoras (1930) (cf. Benjamin 1986, 186). Ora, o rei exige de seu cozinheiro que reproduza exatamente a mesma omelete de amoras que comeu após uma fuga em uma guerra e que foi feita por uma velha senhora no momento que o rei e seu pai estavam quase sucumbindo de fome e cansaço. A memória dessa omelete é "clara" para o rei; é essa realidade que ele exige que seja reproduzido por seu cozinheiro (ameaçando-o de morte, caso não consiga fazer tal omelete). Sábio, o cozinheiro está certo de que seria incapaz de reproduzir a memória do rei, mesmo conhecendo todos os segredos de uma omelete de amoras (e pede para ser morto imediatamente). Todo o sabor está em sua memória e nenhuma omelete poderia ser suficientemente "completa" para ter o sabor do perigo da batalha, a cautela do perseguido, o calor do fogo etc., - tudo aquilo que é simbolicamente eficaz nessa omelete. O que é real para o rei, sua construção de uma memória de um sabor, é inacessível para um cozinheiro reproduzir (e por isso, talvez, o rei perdoa o cozinheiro por não tentar), senão saboreado por uma narração que provavelmente só nos traz um rasto do que o rei lhe exigia - a reconstrução de uma cidade antiga, em que encontramos somente alguns vestígios...

\section{REFERÊNCIAS}

AGAMBEN, Giorgio. O sacramento da linguagem - Arqueologia do juramento (Homo Sacer II, 3). Trad. Selvino José Assmann. Belo Horizonte: Editora UFMG, 2011.

AGAMBEN, Giorgio. Infância e história. Trad. Silvio Mattoni. Buenos Aires: Adriana Hidalgo editora, 2007.

BENJAMIN, Walter. Documentos de cultura, documentos de barbárie: escritos escolbidos. Trad. Celeste H. M. Ribeiro de Sousa (Et al.). São Paulo: Cultrix: Editora da USP, 1986.

BENJAMIN, Walter. Obras Escolhidas I - Magia e técnica, arte e política. Trad. Sérgio Paulo Rounanet. São Paulo: Brasiliense, 1994.

BENJAMIN, Walter. Obras Escolbidas II - Rua de mão única. Trad. Rubens Rodrigues Torres Filho e José Carlos Martins Barbosa. São Paulo: Brasiliense, 1987.

BUCCI, Eugênio; KEHL, Maria Rita. Videologias. São Paulo: Boitempo, 2004.

DAMIÃO, Carla Milani. Sobre o declínio da "sinceridade" - Filosofia e autobiografia de JeanJacques Rousseau a Walter Benjamin. São Paulo: Loyola, 2006.

DEBORD, Guy. La Société du spectacle. Paris: Gallimard, 1992.

DUNKER, Christian I.L. Estrutura e constituição da clínica psicanalítica. São Paulo: Annablume, 2011.

DUNKER, Christian I.L. Christian I. L. Mal-estar, sofrimento e sintoma. São Paulo: Boitempo, 2015.

EHRENBERG, Alain. O culto da performance - Da Aventura empreendedora à depressão nervosa. Trad. Pedro Bendassolli. Aparecida: Ideias \& Letras, 2010.

EHRENBERG, Alain. La fatigue d'être soi - Dépression et société. Paris: Odile Jacob, 1998. 
FREUD, Sigmund. Moisés e o Monoteísmo, Compêndio de psicanálise e outros textos (1937-1939) - Vol. 19. Trad. Paulo César de Souza. São Paulo: Companhia das letras, 2018.

FREUD, Sigmund. Primeiras publicações psicanaliticas (1893-1899) - Vol. III. Trad. sob a direção de Jayme Salomão. Rio de Janeiro: Imago, 1996.

FREUD, Sigmund. Três ensaios sobre a teoria da sexualidade, Análise fragmentaria de uma bistérica ("O caso Dora") e outros textos (1901-1905) - Vol. 6. Trad. Paulo César de Souza. São Paulo: Companhia das letras, 2016.

FREUD, Sigmund; BREUER, Josef. Estudos sobre a histeria (1893-1895) - Vol. 2. Trad. Laura Barreto. São Paulo: Companhia das Letras, 2016.

GABBI JR., Osmyr Faria. Notas a projeto de uma psicologia - As origens utilitaristas da psicanálise. Rio de Janeiro: Imago, 2003.

GAGNEBIN, Jeanne Marie. Lembrar escrever esquecer. São Paulo: Ed. 34, 2009.

GINZBURG, Natalia. Léxico familiar. Trad. Homero Freitas São Paulo: Companhia das Letras, 2018.

GINZBURG, Natalia. As pequenas virtudes. Trad. Maurício Santana Dias. São Paulo: Companhia das Letras, 2020.

HANSEN, Marise. Os laços que unem Clarice e Carolina. In: HANSEN, Marise. Revista Quatro cinco um (Folha de São Paulo). São Paulo, agosto de 2020.

GOETHE, Johann W. von. Memórias: poesia e verdade. Trad. Leonel Vallandro. Brasília: Editora Universidade de Brasília, 1999.

HARVEY, David. Condição Pós-moderna - Uma pesquisa sobre as origens da mudança cultural. Trad. Adail Sobral; Maria Gonçalves. São Paulo: Loyola, 2001.

JESUS, Carolina Maria. Quarto de despejo. São Paulo: Ática, 2014.

KEHL, Maria Rita. Ressentimento. São Paulo: Casa do Psicólogo, 2004.

KEHL, Maria Rita. Maria Rita. História e Repetição. In: Os paradoxos da repetição. Organizadora: Dominique Finguermann. São Paulo: Annablume, 2014.

LACAN, Jacques. A instância da letra no inconsciente ou a razão desde Freud. In: Escritos. Trad. Vera Ribeiro. São Paulo: JZE, 1998.

LACAN, Jacques. Le Séminaire I - Les Écrits Techniques de Freud (1953-1954). Paris: Seuil, 1975.

LACAN, Jacques. Le Séminaire XVI - D’un Autre à l'autre (1968-1969). Paris: Seuil, 2006.

LEVI, Primo. Os afogados e os sobreviventes. Trad. Luiz Sérgio Henriques. São Paulo: Paz e Terra, 2004.

MANZI, Ronaldo. Uma leitura sobre ideologia, mídia e educação - O que é real e o que é ficção? Curitiba: Brazil Publishing, 2020.

MANZI, Ronaldo. Memória, ato performativo e patologia do social - De permeio com a filosofia, a psicanálise e a literatura. Curitiba: Kotter, 2019.

MERLEAU-PONTY, Maurice. Phénoménologie de la Perception. Paris: Gallimard, 1967.

MERLEAU-PONTY, Maurice. Signes. Paris: Gallimard, 2000.

NIETZSCHE, Friedrich. Segunda consideração intempestiva - Da utilidade e desvantagem da bistória para a vida. Trad. Marco Antônio Casanova. Rio de Janeiro: Relume Dumará, 2003. 
REIS, Maria L. de O. Infância e memória. Histórias de psicanálise com crianças. Curitiba: Editora CRV, 2016.

REIS, Maria L. de O. Da experiência de perda à perda de experiência: um estudo sobre a Erfahrung na teoria psicanalítica, na filosofia e na clinica. 2015. Tese (Doutorado em Psicologia Clínica) - Instituto de Psicologia, University of São Paulo, São Paulo, 2015. doi:10.11606/T.47.2015.tde-29092015-165550. Acesso em: 16 ago. 2020.

SAFATLE, Vladimir; MANZI, Ronaldo (Orgs.). A filosofia após Freud. São Paulo: Humanitas, 2008.

SIBILIA, Paula. O show do Eu - A intimidade como espetáculo. Rio de Janeiro: Contraponto, 2016.

TATIT e ROSA. Pra não dizer que Freud e Lacan não falaram de solidão. Revista Psicologia e Saúde. São Paulo, v. 5, n. 2, p. 136-143, jul./dez. 2013.

\section{Filmografia}

ETERNAL Sunshine of The Spotless Mind (2004). Direção: Michael Gondry. Roteiro: Charlie Kaufman. 